\title{
SLC38A9 Gene
}

National Cancer Institute

\section{Source}

National Cancer Institute. SLC38A9 Gene. NCI Thesaurus. Code C142760.

This gene is involved in signaling and lysosomal amino acid transport. 